\title{
Conflict Management Approaches Principals Adopt For Effective Administration of Secondary Schools in Ebonyi State
}

\author{
Dr. S. N. Aja \\ Department of Educational Foundations, Faculty of Education, Ebonyi State University, Abakaliki
}

\begin{abstract}
This study focused on finding out the conflict management strategies principals adopt for effective administration of secondary schools in Ebonyi State of Nigeria. Two research questions and one hypothesis were formulated to guide the study. The study adopted descriptive survey research design. The population of the study comprised all the two hundred and twenty one (221) principals and three thousand two hundred and eighty five $(3,285)$ teachers in the 221 public secondary schools in Ebonyi State, Nigeria. Simple random sampling technique was used to select ten (10) teachers from each of the thirty (30) secondary schools used for the study. This gave a total of three hundred (300) respondents as the sample size. Structured questionnaire developed by the researcher was used for data collection. The data collected in respect of the research questions were analysed using mean scores while T-test statistics was used to test the hypothesis. The finding of the study revealed that principals use both intervention and non-intervention conflict management strategies. However, a significance difference was observed in the rating of principals' use of the two broad conflict management approaches. Based on the findings, it was recommended that principals should be more concerned with looking for early warning of conflict to address it rather than allowing it to escalate. Also principals should be sponsored by the government to regularly attend conferences to keep themselves abreast of the global best practices in conflict management because of the implication of conflict in school administration.
\end{abstract}

Keywords: Conflict management approaches (strategies) ,effective administration and secondary school.

\section{Introduction}

Conflict management is a crucial issue in school administration because no meaningful teaching and learning can take place in a conflict ridden environment. Considering the fact that where two or more people are together there is bound to be disagreement which when left unattended result to conflict. Some school administrators view conflict as a negative situation which must be avoided at all cost but in reality conflict necessitates management because it creates opportunity for personal growth especially when proper strategy is advanced for solving the conflict. Principals as the administrative heads of secondary schools are faced with conflicts in the bid to influence and co-ordinate school resources for goal attainment. Benson (2011) noted that school principals are faced with conflicts emanating from their administrative style, policy implementation, supervision of instruction, examination malpractice, illegal levies, staff posting and transfer, Parent-Teachers Association (PTA) and other school based committees as well as school related issues. It is therefore necessary that school managers or administrators should be knowledgeable in the conflict management strategies. Conflict according to Ulo (2011), is a controversy or divergence of opinion between two or more people in an organisation about something that was not done or to be done in a work environment in which opposing views are strongly held. Chaturvedi (2006), described conflict as an opposition or competition between two or more forces arising either from the pursuit of incompatible goals or a class of rival opinions. In his contribution Omoike (2014), defined conflict as that which could happen between two or more people or groups with incompatible goals in an organisation.
From the foregoing definitions, it could be deduced that conflict connotes disagreement, controversy, opposition, dispute and resistance between persons, groups or organizations as it affects the interest or goal of each party. Conflict is inevitable especially in a bureaucratic organisation where members are expected to comply with the laid down rules and regulations guiding the organisation. Marshall and Moris cited in Ossai and Nwalado (2011), identified two major causes of conflict in educational institutions which include behavioural and structural based conflict. This implies that conflict may manifest through personality traits, beliefs and ideologies which when at crossroad lead to quarrelling, fighting, refusal to take order from relevant authorities, excessive show of power by the administrator, and high level of indiscipline among staff of the institution. The negative consequences of conflict in any organisation cannot be over-emphasized as its implication on people's lives and properties are enormous. Grasier cited in Nwofia (2015), observed that conflicts have significant cost associated with how to manage them and their consequences. He enumerated the cost of conflict to include direct cost, production cost, continuity cost and emotional cost. It is on the backdrop of the enormous negative consequences attributed to conflict in our secondary schools that the need to put in place the systematic mechanisms through which conflict could be handled termed conflict management strategies which this study sought become imperative.

Behfar, Peterson, Mannis and Trochion (2008), defined conflict management as a process by which organisation deal with a major events or events that threatens the organisation, its stakeholders and the general public. This gives rise to different strategies and styles or techniques administrators adopt in managing conflicts. Authorities in 


\section{International Journal of Science and Research (IJSR) \\ ISSN (Online): 2319-7064}

Index Copernicus Value (2013): 6.14 | Impact Factor (2014): 5.611

dispute and conflict management have identified the following styles of conflict management used by leaders in various organizations. They include: accommodation, compromise, collaboration, competition, withdrawal or avoidance (Ohio Commission on dispute and conflict management report cited in Nwofia, 2015). Also, Cross (1999) and Demer (2002), identified arbitration, mediation, negotiation, reconciliation bargaining, problem solving and peace-making through the use of force as some of the strategies for conflict management in the organisation.

Reitie cited in Ossai and Nwalado (2011), grouped conflict management strategies or approaches into two categories viz: intervention and non-intervention approaches. To him, in the non-intervention strategies administrators do not try to modify, settle or hinder conflict rather they allow the parties concern to resolve the conflict themselves examples of such strategies include: avoidance, bargaining or compromising, politics, bribing collaborative and integrative problem solving; while in intervention approach, the administrator being conscious of a conflict situation intervene to modify or settle the conflict between parties involved examples of such strategies include smoothing, forcing, deterrence or detraction, majority rule, resort to rules, altering the human variable, changing the individuals involved, restructuring the organisation, expansion of resources and mutual personnel exchange. It is widely believed that the principal apart from doing administrative duties is also community relation officer, a facilitator, a catalyst to positive change, staff developer, quality provider, evaluator and importantly a conflict manager. In carrying out these duties, the principal encounters series of obstacles that tests his/her ingenuity; here success largely depend on the principal's personal traits and other variable like education qualification, work experience and school location and other demographic factor. It is therefore, necessary that the school administrators as the chief executives and managers of various educational institutions must value peace, be credible, knowledgeable and experienced in order to bring expertise into bare in identifying and solving conflict situation for administrative effectiveness.

\section{Statement of the Problem}

School administration has been adversely affected by educational administrators inability to manage conflicts when they manifest. Many administrators handle conflict by trial and error approach because they lacked specific procedures and methods of managing conflicts. The rampant cases of strike actions by workers, student riots or unrests and demonstrations of different degrees which are experienced on regular basis in our various educational institutions are not unconnected with poor management of conflict situations. The consequences of these debilitating conditions can better be imagined and the need for the administrator to live up to their responsibilities is not an over statement. Conflicts and their attendant problem have severally resulted to complete breakdown of the administrative process in secondary schools. It is in the light of the above that the problem of this study is apt as it is posed in a question form thus: what are the conflict management approaches the principals could adopt for effective administration of secondary schools?

\section{Purpose of the Study}

The main purpose of the study was to find out conflict management approaches principals adopt for effective administration of secondary schools in Ebonyi State of Nigeria. Specifically, the study sought to find out:

(1) The intervention conflict management strategies principals adopt for effective administration of secondary schools in Ebonyi State.

(2) The non-intervention conflict management strategies principals adopt for effective administration of secondary schools in Ebonyi State.

\section{Significance of the Study}

The findings of this study will be of great importance to school administrators, educational managers and all the stakeholders of the education industry. The finding of the study will help school administrators to identify suitable strategies necessary for handling conflict situations in order to prevent it because prevention they say is better than cure.

Educational managers such as the heads of various school boards and commission as well as ministries of education will use the result of this study to prepare training programme for school administrators on the best conflict management practices.

The entire public and the stakeholders of education will benefit from this study because if the recommendations proffered are implemented, they will go a long way in ensuring that most conflict situations are avoided then the tranquil and conducive teaching and learning environment will be guaranteed in our secondary school system.

\section{Scope of the Study}

The study was carried in public secondary schools in Ebonyi State of Nigeria to examine conflict management strategies principals adopt to enhance their administrative effectiveness.

\section{Research Questions}

The following research questions were formulated to guide the study:

(1) What are the intervention conflict management strategies principals adopt for effective administration of secondary schools in Ebonyi State?

(2) What are the non-intervention conflict management strategies principals adopt for effective administration of secondary schools in Ebonyi State?

\section{Hypothesis}

$\mathrm{Ho}_{1}$ : There is no significant difference in the use of intervention and non-intervention conflict management strategies among principals in secondary schools in Ebonyi State? 


\section{International Journal of Science and Research (IJSR) \\ ISSN (Online): 2319-7064 \\ Index Copernicus Value (2013): 6.14 | Impact Factor (2014): 5.611}

\section{Research Methods}

The study aimed at finding out conflict management approaches principals adopt for effective administration of secondary schools in Ebonyi State. The study adopted descriptive survey research design. The population of the study comprised all the two hundred and twenty-one (221) principals and three thousand two hundred and eighty five $(3,285)$ teachers in the 221 public secondary schools in Ebonyi State. Simple random sampling technique was used to select thirty (30) secondary schools across the Abakaliki, Onueke and Afikpo education zones of Ebonyi State. Researcher-structured questionnaire tagged "Principal Conflict Management Strategies Questionnaire" (PCMAS) was used as the instrument for data collection. The instrument, has 2 sections: Section $\mathrm{A}$ and $\mathrm{B}$, section $\mathrm{A}$ contains the demographic data while section B contains a 20 questionnaire item patterned on a 4-point rating scale to elicit response from respondents on the intervention and non-intervention conflict management strategies principals adopt. The instrument was validated by three expert s from department of Educational Foundations in the Ebonyi State University, Abakaliki. The reliability estimate through testretest method was 0.85 . This figure confirmed that the instrument was suitable for the study. To collect data, the researcher personally visited the schools and explained the purpose of the study to respondent as well as how to fill the questionnaire. This measure helped to achieve a hundred percent rate of return. Data collected were analysed using mean score while $\mathrm{T}$-test statistics was used for testing the hypothesis at 0.05 alpha level.

\section{Results}

The data collected in respect to the research questions were presented and analysed as shown in tables below:

Research Question One: What are the non-intervention conflict management strategies principals adopt for effective administration of secondary schools?

Table 1: Mean response of respondents on non-intervention conflict management strategies adopted by principles in the administration of secondary schools.

\begin{tabular}{|c|c|c|c|c|c|c|c|c|c|c|}
\hline $\mathbf{S} / \mathbf{N}$ & Item Statement & SA & A & D & SD & $\mathbf{N}$ & FX & $\mathbf{X}$ & SD & DEC \\
\hline 1 & $\begin{array}{l}\text { Principal pays no attention to conflict situation thereby } \\
\text { leaving the resolution of the conflict to fate or chance (i.e. } \\
\text { avoidance strategy) }\end{array}$ & 30 & 60 & 150 & 60 & 300 & 660 & 2.2 & .873 & Reject \\
\hline 2 & $\begin{array}{l}\text { Principal one or both parties in a conflict situation to give up } \\
\text { something in order to reach a solution (i.e. bargaining } \\
\text { strategy) }\end{array}$ & 0 & 180 & 90 & 30 & 300 & 780 & 2.6 & 672 & Accept \\
\hline 3 & $\begin{array}{l}\text { Principal allows conflicting parties to struggle until the } \\
\text { stronger wins while the weaker loses hence the loser will be } \\
\text { forced to quit its stand while the winner takes it all (i.e. } \\
\text { divide and rule/politics strategy). }\end{array}$ & 90 & 0 & 90 & 120 & 300 & 660 & 2.2 & 1.251 & Reject \\
\hline 4 & $\begin{array}{l}\text { Principal allows one party in a conflict to accept } \\
\text { compensation from the other as a condition for ending a } \\
\text { conflicting situation (i.e. bribing strategy) }\end{array}$ & 60 & 30 & 150 & 60 & 300 & 720 & 2.4 & 1.007 & Reject \\
\hline 5 & $\begin{array}{l}\text { Principal allows the parties in conflict to come together to } \\
\text { propose alternative solutions and evaluate the alternatives } \\
\text { until they arrive at one that solves the problem to } \\
\text { satisfaction of both parties is found (i.e. problem solving } \\
\text { strategy) }\end{array}$ & 90 & 60 & 90 & 60 & 300 & 780 & 2.6 & 1.115 & Accept \\
\hline 6 & $\begin{array}{l}\text { Compromise: principal stands in between the conflicting } \\
\text { persons or group so that they can shift ground and agree on } \\
\text { middle course in form of giving and take. }\end{array}$ & 60 & 90 & 150 & 0 & 300 & 810 & 2.7 & .782 & Accept \\
\hline 7 & $\begin{array}{l}\text { Collaboration: principal allows the conflicting parties the } \\
\text { opportunity to discuss openly so that they will arrive at what } \\
\text { will be beneficial to both parties by not allowing personal } \\
\text { attacks to interfere with the issue under contest (i.e. open } \\
\text { door policy }\end{array}$ & 90 & 60 & 120 & 30 & 300 & 810 & 2.7 & 1.007 & Accept \\
\hline 8 & $\begin{array}{l}\text { Catharsis: principal engages the protagonists in other } \\
\text { activities that will help to let off pent up emotions in the } \\
\text { individual }\end{array}$ & 30 & 90 & 90 & 90 & 300 & 660 & 2.2 & .981 & Reject \\
\hline 9 & $\begin{array}{l}\text { Empathy: principal tries to put him/herself in the position of } \\
\text { feeling of the aggrieved or conflicting parties. }\end{array}$ & 30 & 90 & 120 & 60 & 300 & 690 & 2.3 & .902 & Reject \\
\hline 10 & $\begin{array}{l}\text { Use of influential person: principal invites highly respected } \\
\text { person(s) in the community to talk or appeal to those in } \\
\text { conflict to bury their differences. }\end{array}$ & 60 & 60 & 120 & 60 & 300 & 720 & 2.4 & 1.022 & Reject \\
\hline & Grand mean \& SD & & & & & & & 2.41 & 0.9612 & \\
\hline
\end{tabular}

The result of data analysed in table one revealed that the respondents agreed that principals mostly adopt bargaining, problem solving, compromise and collaboration conflict management strategies in the management of conflicts in secondary schools; while they disagree that principals use avoidance, divide and rule, bribery, carthansis and use of influential persons as conflict management strategies in the administration of secondary schools. In all the grand mean of 2.43 which is below the criterion point of 2.5 show that principals do not use most $f$ the non-intervention conflict

\section{Volume 4 Issue 12, December 2015}




\section{International Journal of Science and Research (IJSR) \\ ISSN (Online): 2319-7064}

Index Copernicus Value (2013): 6.14 | Impact Factor (2014): 5.611

management strategies in the management of conflicts in secondary schools.

Table 2: Mean response of respondents on intervention conflict management strategies adopted by principals in the administration of secondary schools in Ebonyi state

Research Question Two: What are the intervention conflict management strategies principals adopt for effective administration of secondary schools?

\begin{tabular}{|l|l|l|l|l|l|l|l|l|l|l|}
\hline$s / n$ & \multicolumn{1}{|c|}{ Item Statement } & $S A$ & $A$ & $D$ & $S D$ & $N$ & $F X$ & $X$ & $S D$ & $D E C$ \\
\hline 1 & $\begin{array}{l}\text { Accommodation/smoothing strategy: principal talks to both parties } \\
\text { by stressing on their common interest and de-emphasizing their } \\
\text { difference diplomatically }\end{array}$ & 60 & 150 & 40 & 0 & 300 & 870 & 2.9 & .701 & Accept \\
\hline 2 & $\begin{array}{l}\text { Forcing/competition or confrontation: principal uses his authority } \\
\text { to resolve the conflict by dictating what the subordinate will abide } \\
\text { by. }\end{array}$ & 90 & 150 & 30 & 30 & 300 & 930 & 3.0 & .896 & Accept \\
\hline 3 & $\begin{array}{l}\text { Deterrence or detraction: principal gives conflicting parties so } \\
\text { much work to do so that they have no time for conflict. }\end{array}$ & 60 & 60 & 30 & 150 & 300 & 630 & 2.1 & .701 \\
\hline 4 & $\begin{array}{l}\text { Dialogue: principal brings the conflicting parties face to face to } \\
\text { express their feeling, grievances and view on the matter. }\end{array}$ & 150 & 120 & 0 & 30 & 300 & 990 & 3.3 & .896 & Reject \\
\hline 5 & $\begin{array}{l}\text { In boxing: principal indentifies the problem factor for the conflict } \\
\text { and subject the matter to public debate to expose its triviality or } \\
\text { emptiness. }\end{array}$ & 30 & 60 & 150 & 60 & 300 & 660 & 2.2 & 1.223 & Reject \\
\hline 6 & $\begin{array}{l}\text { Arbitration/negotiation: principal sets up panel to look into the } \\
\text { conflicting situation with the view to setting it through appealing } \\
\text { to the conscience of those in conflict. }\end{array}$ & $\mathbf{6 0}$ & $\mathbf{6 0}$ & $\mathbf{6 0}$ & $\mathbf{1 2 0}$ & $\mathbf{3 0 0}$ & $\mathbf{6 6 0}$ & $\mathbf{2 . 2}$ & $\mathbf{1 . 1 4 6}$ & Reject \\
\hline 7 & $\begin{array}{l}\text { Majority rule: principal allows the conflicting situation to be put to } \\
\text { vote so that majority view will have the way while the minority } \\
\text { will have their say. }\end{array}$ & 60 & 30 & 60 & 150 & 300 & 600 & 2.0 & 1.185 & Reject \\
\hline 8 & $\begin{array}{l}\text { Resort to rule: principal applies the relevant rules in deciding } \\
\text { disputes }\end{array}$ & 60 & 150 & 60 & 30 & 300 & 840 & 2.8 & .873 \\
\hline 9 & $\begin{array}{l}\text { Restructuring the organization: principal change, relocate or rotate } \\
\text { member of the conflicting groups and redefining their talks. }\end{array}$ & 0 & 90 & 130 & 60 & 300 & 630 & 2.1 & Reject \\
\hline 10 & $\begin{array}{l}\text { Changing the individuals or ring leaders: principal recommends } \\
\text { for the removal of the key actors in the conflict situation. }\end{array}$ & 60 & 150 & 30 & 60 & 300 & 810 & 2.7 & 1.007 \\
\hline Grand Mean and SD & Reject \\
\hline
\end{tabular}

From the data analysed in table two, it is evident that the respondents agreed that principals use accommodation, competition, dialogue resort to rule and changing the individuals or ring leaders in the conflict as conflict management strategies, while they disagree on principals use of deterrence in boxing, arbitration, majority rule and restructuring the organization as conflict management strategies in the management of conflicts in secondary schools. The grand mean of 2.54 is an indicative that principals mostly adopt intervention approaches in the management of conflict in secondary schools in Ebonyi state.

\section{Result of the Research Hypothesis}

Hypothesis One: There is no significant difference in use of intervention and non-intervention conflict management strategies among principals in secondary schools in Ebonyi state.

Table Three: T-test analysis of views of respondents on use of intervention and non-intervention conflict management strategies by principals in secondary schools.

\begin{tabular}{|l|l|l|l|l|l|l|l|}
\hline Variables & $\mathrm{N}$ & Mean $(\mathrm{x})$ & $\mathrm{SD}$ & $\mathrm{DF}$ & $\mathrm{T}$-cal & T-crit & Remarks \\
\hline Intervention approach & 300 & 2.5 & 0.9507 & 298 & 0.856 & 0.370 & $\mathrm{~S}$ \\
\hline Non-intervention approach & 300 & 2.4 & 0.9612 & & & & \\
\hline
\end{tabular}

Key: $\mathrm{N}=$ number of respondents; SSD = standard deviation; $\mathrm{DF}=$ degree of freedom; $\mathrm{T}$-cal $=\mathrm{T}$ calculated; $\mathrm{t}$-crit. $=\mathrm{t}$ critical and $\mathrm{S}=$ significant.

Data in table 3 shows that t-calculated $(0.856)$ is greater than t-critical (0.370); hence the alternative is uphold against the null hypothesis that no significant difference exist in the view of teachers on principals use of intervention and nonintervention conflict management strategies. This implies that there is significant difference in the principal's use of intervention and non-intervention conflict management approaches in secondary schools.

\section{Summary of Findings}

1. The findings have shown that principals use more of intervention conflict management strategies in the management of conflicts in secondary schools.

2. The result of the research hypotheses also revealed that there is significant difference in the principal's use of intervention and non intervention conflict management strategies in the management of conflict ion secondary schools. 


\section{Discussion of the Findings}

Result on non-intervention conflict management strategies adopted by principals in the administration of secondary schools shows that most principals adopt bargaining, problem solving, compromise and collaboration conflict management strategies in the management of conflicts to ensure effective administration in secondary schools. This findings is contrary to the one identified by Umoren (2001) who observed that most secondary school administrators prefer to adopt avoidance conflict management strategy for managing conflicts in secondary schools in Uyo educational district of cross river state.

On the intervention conflict management strategies adopted by principals, the result show that most principals use accommodation competition, dialogue, resort to rule and changing the individuals or ring leader in the conflict as conflict management strategies for managing conflicts in secondary schools in Ebonyi state. This agreed with the findings of Umoren (2001), who identified that most school heads adopt smoothing and persuasion conflict management strategies for managing conflict in their schools.

Finally, the result of t-test analysis revealed that significant different exist in the view of the respondents on principals' use of intervention and non-intervention conflict management approaches as strategies for the management of conflict ins secondary schools in Ebonyi state of Nigeria.

\section{Conclusion}

The main thrust of this study is to find out the conflict management strategies principals adopt for smooth running of their schools in Ebonyi state. It is worthy to mention that there is no universal conflict management strategies but the strategy or strategies to adopt is dependent on the situation one finds him or herself. Therefore, it is the duty of the principal to be conversant with as many conflict management strategies as possible so that he or she could apply one appropriate in a given conflict situation. This will go a long way in achieving the desired conducive school atmosphere that will guarantee effective administration of secondary schools in Ebonyi state of Nigeria.

\section{Recommendations}

Based on the findings, the research wish to state that conflict is inevitable in any organization therefore principals should be more concerned with looking for really warning of conflict to address it rather than allowing it to be blown into full crisis.

Also, principals should be sponsored by the government to attend conferences to keep themselves abreast of the global best conflict management practices. Above all, principals should not be allowed to stay in one school for more than five years. All these will help to reduce or eliminate conflict situation and thus give the principals the opportunity to concentrate on his or her duties to ensure effective administration in secondary schools in Ebonyi state of Nigeria.

\section{References}

[1] Behfar, K. J., Peterson, R. S., Mannis, E. A. and Trochion, W.M.K. (2008). The Critical Role of Conflict Resolution in terms: a close look at the links between conflict type, conflict management strategies and team outcomes. Journal of Applied Psychology 93: 170-188.

[2] Benson, I.D. (2011). Causes of Conflicts in our Secondary Schools and Related Unrest. Jos: Marx and Coy. Inc.

[3] Chaturvedi, A. K. (2006). Academic Dictionary of Political Science. New Delhi: Academic Publishers.

[4] Cross, S. (1999). The Models of Conflict Resolution: Effect on Inter-group Expectancy and Attitudes. New York: Fall Publishing House.

[5] Demer, J. (2002). Settling International Dispute (Retrieved online: http://www.eia.doc.gov/emen.

[6] Ossai, A.G. and Nwalado, E.N. (2011). Conflict Management in Educational Institutions in the $21^{\text {st }}$ Century Nigeria. In A.O. Abolade; C.M. Ogbodo and B.U. Maduewesi (eds.) Contemporary Issues in Nigeria Education. Onitsha: west and Solomon Publishing Coy. Ltd.

[7] Omoike, D. (2004). Educational Management. A skill building Approach. Charles and Patrick Booksmith House Ltd.

[8] Nwofia, B. N. (2015). Conflict Manifestations and Management in Secondary School in Ebonyi State, Nigeria. Unpublished PhD thesis proposal. Ebonyi State University, Abakaliki.

[9] Ulo, F.O. (2011). Element of Management: A Book of Reading. Enugu: Rhyce Kerek Publishers.

[10] Umoren, D.N. (2001). Comparative analysis of conflict management strategies among primary and post primary school administrators in Uyo Educational District of Cross River State. International Journal of Education Administration, Planning and Research (1) 115-124. 